\title{
Research on The Preference of Seasonal Landscape Based on UGC -- A Case Study of Guilin City
}

\author{
Yaming Fan ${ }^{l}$, Zhengyang Sun ${ }^{l *}$, and Hui Liu \\ ${ }^{1}$ School of Tourism and Landscape Architecture, Guilin University of Technology, 541006 Guilin, Guangxi, China
}

\begin{abstract}
With the continuous advancement of the construction of beautiful China, plant landscape, as an important tourism resource, has been favoured by the majority of people in recent years, and tourism activities with the theme of seeing flowers and leaves are in full swing all over the country. This paper takes the plant landscape of Guilin as the research object, through the collection and collation of relevant UGC data, studies and discusses the tourist preference of Guilin characteristic plant landscape under the background of big data era, and then puts forward suggestions on the construction and optimization of Guilin plant tourism landscape.
\end{abstract}

\section{Introduction}

Guilin is an important tourism resource because of its variety of plant landscape resources and abundant seasonal changes. Therefore, based on tourists' preference, it is of great significance to study the spatiotemporal differentiation of seasonal landscape constructed by plants and analyze the correlation between seasonal landscape and tourists' perception, which is of great significance to enhance the attractiveness of plant landscape and the construction of tourist destinations. Tourism related content published and updated by tourists on the Internet is called "user generated content", hereinafter referred to as "UGC" [1]. "UGC" is generated by tourists spontaneously, which has higher credibility than the information provided by marketing agencies based on the purpose. At the same time, it can reflect tourists' perception of tourism destination image comprehensively. Its credibility and availability make it an important medium for shaping destination image and influencing tourists' decision-making [2]. Based on the investigation and statistics of seasonal landscape created by plants in Guilin, this paper explores the impact of various seasonal landscapes on tourists' attraction through statistics and comparative analysis, and reveals the temporal and spatial differences of different seasonal landscape resources and their correlation with tourists' perception, so as to provide theoretical support for the construction of Guilin International tourist attractions and the development of global tourism.

\section{Research methods}

\subsection{Data sources}

ROST CM6 is a word frequency analysis software, which can analyze different information sources, such as word segmentation, semantic elements extraction, emotional orientation, etc., and build a relationship network, and then carry out quantitative and qualitative analysis, so as to complete the processing and mining of text content [3]. Through inputting the keyword set on ctrip.com, we can get the comments about different plant landscapes in Guilin, sort out the irrelevant comments, intercept about 3000 valid comments from January 2019 to January 2020, and guide them into the software to complete the text preprocessing. Baidu Index is a data sharing platform to record the behavior of Internet users. It records the search frequency of a high-frequency word in a period of time to reflect the network attention of the keyword in that period. It can also carry out crowd portraits of Internet users and provide information on the location, age composition and gender composition of Internet users [4]. Using Baidu Index, we can understand the situation of Guilin plant landscape searched by Internet users from January 2019 to January 2020 through Baidu, and analyze the heat of each landscape and collate it into data [5].

\subsection{Data processing}

The content of saved word documents is analyzed by using the software of rostcontent mining. Firstly, the document content is divided into several words by using the "word segmentation" function of the software, and then the "Filter vocabulary" function is used to filter out the words irrelevant to the research, and a new analysis document is formed as the basis for subsequent analysis. Based on this, we integrate the words with similar meaning in statistics, such as "Guilin city", "Guilin" and so on. The search scope will be limited to the region and plant landscape, not limited to the site, the whole network related search, and the file type is set to "all web pages and files" to increase the comprehensiveness of the data.

In order to ensure timeliness, the selection of results will be limited to the latest year. Baidu advanced search 
conditions include all the following keywords, including the following complete keywords, including any of the following keywords, excluding the following four keywords. "Do not include the following keywords" condition does not need to be used, using Baidu advanced search, limited syntax to get about the search results [6].

\section{Analysis of research results}

The author uses googlearth software to obtain the geographical coordinates of plant landscape, through ArcGIS software combined with Guilin administrative district map, the plant landscape is positioned in the form of point elements, and then get the distribution of plant landscape in Guilin. The geographic data is from the 1:250000 SHP map data of Guilin city. All the data are in Xi'an 80 coordinate system and Gauss Kruger projection. Guilin city is composed of six districts under the jurisdiction of Guilin, namely Xiufeng District, Diecai District, Xiangshan District, Qixing District, Yanshan district and Lingui district. According to the statistics, there are 21 important plant Tourism Landscapes in the urban area. The plant landscape resources of Qixing district are the most, while the colorful area is the least. In the country area, there are 31 important plant tourism landscapes, which are distributed in all areas except Lipu County and Yongfu county.

As a whole, the plant landscape is concentrated in the northwest southeast direction, and the southwest and northeast parts are less distributed. Among them, Lingchuan County has the largest number of resources, with 6 places, accounting for $20 \%$ of the total number of plant Tourism Landscapes in the countryside [7]. Overall, the plant landscape distribution in Guilin conforms to the spatial pattern of "one center (Guilin urban area) and two sub centers (Yangshuo and Xing'an)" in the overall planning of Guilin Tourism Development (2001-2020).

\subsection{Plant landscape distribution of four seasons in Guilin}

(1) Distribution of plant landscape in spring in Guilin There are 23 main ornamental sites for plant tourism in spring in Guilin city. The main plant species are flowering trees and shrubs and spring flowers. On the whole, it shows the main color of red, and the viewing time is mainly from March to April. It is widely distributed, including Xiufeng District, Xiangshan district and Yanshan District, and six counties including Linchuan County, Xing'an County and county, as shown in Figure 1.

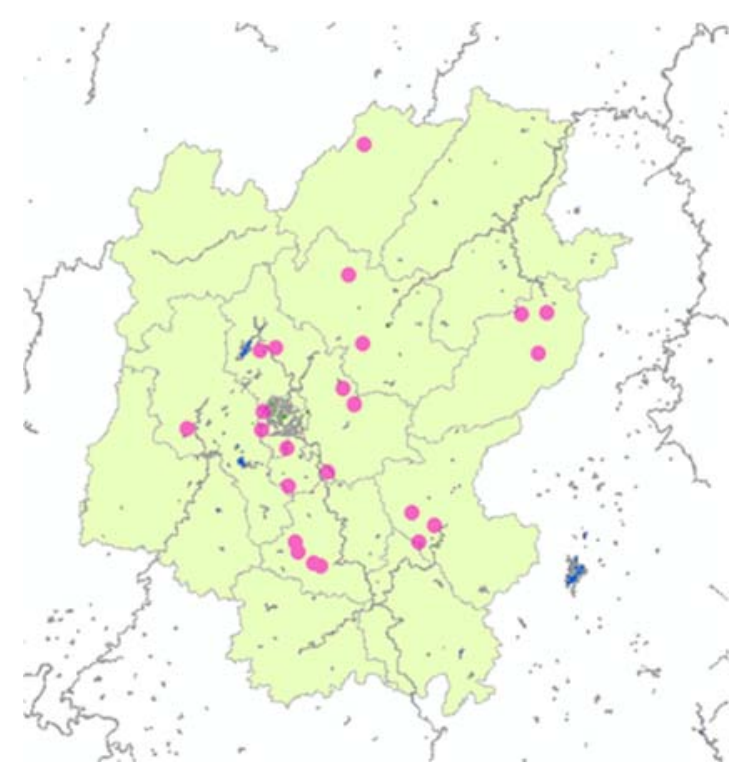

Fig. 1. Plant landscape distribution in spring

Table 1. A survey of representative plants in major industrial

\begin{tabular}{|c|c|c|c|}
\hline Plant landscape & name & section & color \\
\hline Peach Of Hai Yang Xiang & Peach & Rosaceae & powder \\
\hline Xi Shan Park & Lotus & $\begin{array}{l}\text { Nymphae } \\
\text { aceae }\end{array}$ & $\begin{array}{l}\text { Pink, } \\
\text { white }\end{array}$ \\
\hline \multirow[t]{2}{*}{ An Long Village } & Lotus & $\begin{array}{l}\text { Nymphae } \\
\text { aceae }\end{array}$ & $\begin{array}{l}\text { Pink, } \\
\text { white }\end{array}$ \\
\hline & & & orange \\
\hline Ai Lian Lotus Garden & Lotus & $\begin{array}{l}\text { Nymphae } \\
\text { aceae }\end{array}$ & powder \\
\hline Yanshan Lotus Base & Lotus & $\begin{array}{l}\text { Nymphae } \\
\text { aceae }\end{array}$ & powder \\
\hline Tang Jia Village & Lotus & $\begin{array}{l}\text { Nymphae } \\
\text { aceae }\end{array}$ & white \\
\hline $\begin{array}{l}\text { Lotus Of Quan Zhou Jian Tang } \\
\text { Town }\end{array}$ & Lotus & $\begin{array}{l}\text { Nymphae } \\
\text { aceae }\end{array}$ & $\begin{array}{l}\text { Pink, } \\
\text { white }\end{array}$ \\
\hline $\begin{array}{l}\text { One Thousand Acres Of Lotus I } \\
\text { n Pingle Town }\end{array}$ & Lotus & $\begin{array}{l}\text { Nymphae } \\
\text { aceae }\end{array}$ & powder \\
\hline Dengba village, gongcheng & Lotus & $\begin{array}{l}\text { Nymphae } \\
\text { aceae }\end{array}$ & $\begin{array}{l}\text { White } \\
\text { and } \\
\text { pink }\end{array}$ \\
\hline
\end{tabular}

(2) Distribution of summer plant landscape in Guilin

According to statistics, there are 9 important plant landscapes in Guilin in summer, among which 8 are planting lotus as the core plant landscape. It can be seen from Table 2 that there is only one kind of ornamental plant lotus in summer plant tourism landscape, which is mainly pink and white, and the color is relatively simple. Compared with spring, the distribution is smaller, mainly concentrated in Xiufeng District, Qixing district and other municipal districts. According to the results of investigation and statistics, pink and white are the main colors of important plant tourism landscape in Guilin in summer. Color richness is weaker than spring, and the color is single. In addition, it can be seen from Figure 2 that the distribution of plant landscape in summer is relatively close to distribution of rivers. compared with other seasons, it has stronger hydrophilicity. 
Table 2. Information Table of plant landscape in summer in Guilin

\begin{tabular}{|c|c|c|c|}
\hline Plant landscape & name & section & color \\
\hline The Drunken Beauty Garden & $\begin{array}{l}\text { Peach } \\
\text { bloss } \\
\text { om }\end{array}$ & Rosaceae & $\begin{array}{l}\text { Pink, } \\
\text { pink }\end{array}$ \\
\hline $\begin{array}{l}\text { Peach blossom forest of haiyang } \mathrm{t} \\
\text { ownship }\end{array}$ & $\begin{array}{l}\text { Peach } \\
\text { bloss } \\
\text { om }\end{array}$ & Rosaceae & $\begin{array}{l}\text { Pink, } \\
\text { red, } \\
\text { white }\end{array}$ \\
\hline $\begin{array}{l}\text { Gongcheng Dalin mountain peach } \\
\text { garden }\end{array}$ & $\begin{array}{l}\text { Peach } \\
\text { bloss } \\
\text { om }\end{array}$ & Rosaceae & $\begin{array}{l}\text { Pink, } \\
\text { pink }\end{array}$ \\
\hline $\begin{array}{l}\text { Peach Blossom Forest of Yingsha } \\
\mathrm{n} \text { diesel Engine Plant }\end{array}$ & $\begin{array}{l}\text { Peach } \\
\text { bloss } \\
\text { om }\end{array}$ & Rosaceae & $\begin{array}{l}\text { Pink, } \\
\text { pink }\end{array}$ \\
\hline $\begin{array}{l}\text { Pear Flower Forest, Lawn Countr } \\
\text { y }\end{array}$ & $\begin{array}{l}\text { Pear } \\
\text { Bloss } \\
\text { om }\end{array}$ & Rosaceae & white \\
\hline $\begin{array}{l}\text { Guanyang Dayen Village pear gar } \\
\text { den }\end{array}$ & $\begin{array}{l}\text { Pear } \\
\text { Bloss } \\
\text { om }\end{array}$ & Rosaceae & white \\
\hline nan xi shan park & $\begin{array}{l}\text { cherr } \\
\text { y } \\
\text { bloss } \\
\text { oms }\end{array}$ & Rosaceae & $\begin{array}{l}\text { Pink, } \\
\text { white }\end{array}$ \\
\hline $\begin{array}{l}\text { gong cheng ping an tao zhuang vi } \\
\text { llage }\end{array}$ & $\begin{array}{l}\text { Hawt } \\
\text { horn } \\
\text { flowe } \\
\mathrm{r}\end{array}$ & Rosaceae & white \\
\hline mo tian ridge & $\begin{array}{l}\text { cucko } \\
\text { o }\end{array}$ & $\begin{array}{l}\text { Rhododen } \\
\text { draceae }\end{array}$ & $\begin{array}{l}\text { Red, } \\
\text { yello } \\
\text { w, } \\
\text { mage } \\
\text { nta, } \\
\text { white, }\end{array}$ \\
\hline maoer mountain & $\begin{array}{l}\text { cucko } \\
\text { o }\end{array}$ & $\begin{array}{l}\text { Rhododen } \\
\text { draceae }\end{array}$ & $\begin{array}{l}\text { Pink, } \\
\text { white, } \\
\text { mage } \\
\text { nta }\end{array}$ \\
\hline yao mountain & $\begin{array}{l}\text { cucko } \\
\text { o }\end{array}$ & $\begin{array}{l}\text { Rhododen } \\
\text { draceae }\end{array}$ & $\begin{array}{l}\text { Pink, } \\
\text { white, } \\
\text {,red }\end{array}$ \\
\hline
\end{tabular}

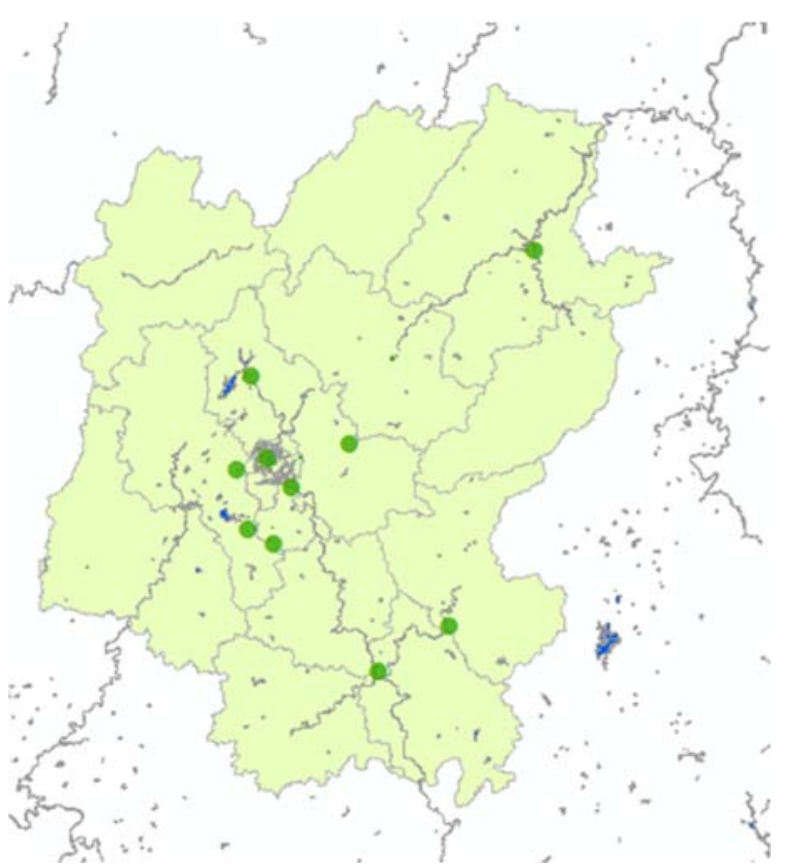

Fig. 2. Plant landscape distribution in summer

(3) Plant landscape distribution in autumn in Guilin According to statistics, there are 7 important plant landscapes in autumn in Guilin, mainly for flower watching (Osmanthus fragrans, etc.), foliage viewing (Ginkgo biloba, rice, etc.), and fruit viewing (persimmon, kumquat, etc.). From the distribution, although the autumn plant landscape distribution range is small, the number is small, mainly concentrated in the municipal area and Longsheng Autonomous County. But its color is relatively rich, including red, yellow, orange, green and so on. The scenic spots are well-known, such as Longji terrace, Osmanthus fragrans, Ginkgo biloba, etc. (Fig. 3)

Table 3. Information Table of plant landscape in autumn in Guilin

\begin{tabular}{|c|c|c|c|}
\hline Plant landscape & Name & Section & Color \\
\hline Longsheng Terrace & rice & $\begin{array}{l}\text { Gramin } \\
\text { eae }\end{array}$ & yellow \\
\hline $\begin{array}{l}\text { Chrysanthemum in } \\
\text { Zhoujia Village }\end{array}$ & $\begin{array}{l}\text { Chrysanth } \\
\text { emum }\end{array}$ & $\begin{array}{l}\text { the } \\
\text { compos } \\
\text { ite } \\
\text { family }\end{array}$ & yellow \\
\hline $\begin{array}{l}\text { Seven Star Park } \\
\text { Osmanthus fragrans }\end{array}$ & $\begin{array}{l}\text { sweet- } \\
\text { scented } \\
\text { osmanthus }\end{array}$ & $\begin{array}{l}\text { Oleacea } \\
\text { e }\end{array}$ & White, orange \\
\hline Guilin flower sea & $\begin{array}{l}\text { triangle } \\
\text { plum }\end{array}$ & $\begin{array}{l}\text { Mirabili } \\
\text { aceae }\end{array}$ & Red \\
\hline $\begin{array}{l}\text { Miscanthus } \\
\text { yaoshanense }\end{array}$ & $\begin{array}{l}\text { Miscanthu } \\
\mathrm{s}\end{array}$ & $\begin{array}{l}\text { Gramin } \\
\text { eae }\end{array}$ & $\begin{array}{l}\text { Beibai, } \\
\text { golden }\end{array}$ \\
\hline Gongcheng Yueshi & $\begin{array}{l}\text { Persimmo } \\
\mathrm{n}\end{array}$ & $\begin{array}{l}\text { Persim } \\
\text { mon } \\
\text { family }\end{array}$ & Orange red \\
\hline Marine Ginkgo biloba & ginkgo & $\begin{array}{l}\text { Ginkgo } \\
\text { bilobac } \\
\text { eae }\end{array}$ & yellow \\
\hline $\begin{array}{l}\text { Bailixincun kumquat } \\
\text { industry demonstration } \\
\text { zone }\end{array}$ & Kumquat & $\begin{array}{l}\text { Rutacea } \\
\text { e }\end{array}$ & golden \\
\hline
\end{tabular}




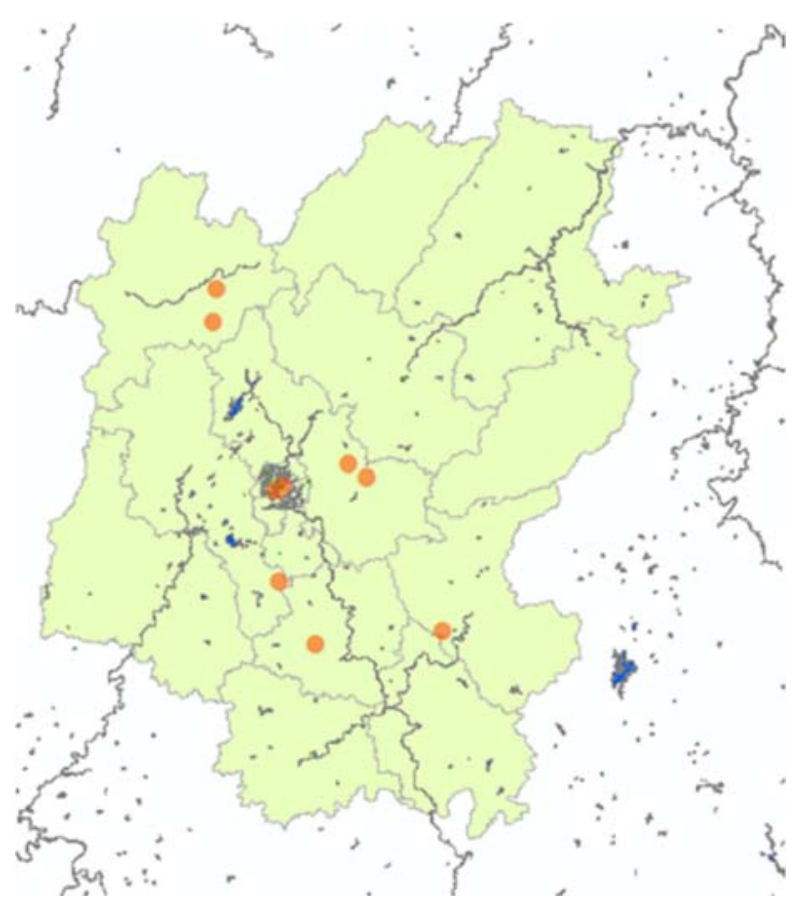

Fig. 3. Plant landscape distribution in autumn

(4) Distribution of winter plant landscape in Guilin It can be seen from the statistics of important plant landscapes in winter in Guilin (see Table 4), This season has a large number of plant scenic spots and rich plant types. Autumn leaf plants account for the vast majority, including Liquidambar formosana, Sapium sebiferum, Ginkgo biloba, Metasequoia glyptostroboides, etc. The color of plants is red, orange and yellow, and red is the main color. Distribution is relatively concentrated, almost all concentrated in Xiufeng District, Diecai District, Xiangshan District, Qixing district.

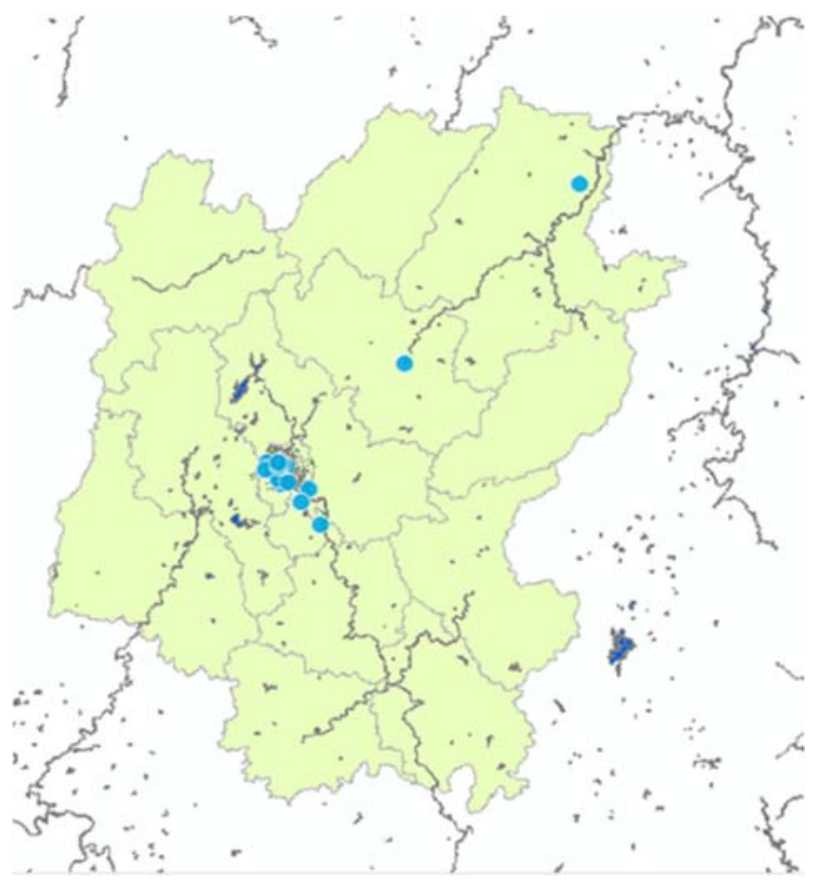

Fig. 4. Plant landscape distribution in winter

Table 4. Information Table of plant landscape in winter in Guilin

\begin{tabular}{|c|c|c|c|}
\hline Plant landscape & Name & Section & Color \\
\hline Wulidian Road & $\begin{array}{l}\text { Liquidamb } \\
\text { ar } \\
\text { formosana }\end{array}$ & $\begin{array}{l}\text { Hamam } \\
\text { elidacea } \\
\mathrm{e}\end{array}$ & $\begin{array}{l}\text { Red, orange } \\
\text { red, yellow }\end{array}$ \\
\hline Xifeng Road & $\begin{array}{l}\text { Liquidamb } \\
\text { ar } \\
\text { formosana }\end{array}$ & $\begin{array}{l}\text { Hamam } \\
\text { elidacea } \\
\text { e }\end{array}$ & $\begin{array}{l}\text { Red, orange } \\
\text { red, yellow }\end{array}$ \\
\hline Seven Star Road & $\begin{array}{l}\text { Liquidamb } \\
\text { ar } \\
\text { formosana }\end{array}$ & $\begin{array}{l}\text { Hamam } \\
\text { elidacea } \\
\text { e }\end{array}$ & $\begin{array}{l}\text { Red, orange } \\
\text { red, yellow }\end{array}$ \\
\hline Chinese tallow Beach & $\begin{array}{l}\text { Chinese } \\
\text { tallow tree }\end{array}$ & $\begin{array}{l}\text { Euphor } \\
\text { biaceae }\end{array}$ & $\begin{array}{l}\text { Red, orange, } \\
\text { yellow }\end{array}$ \\
\hline Zizhou red leaf & $\begin{array}{l}\text { Liquidamb } \\
\text { ar } \\
\text { formosana }\end{array}$ & $\begin{array}{l}\text { Hamam } \\
\text { elidacea } \\
\text { e }\end{array}$ & $\begin{array}{l}\text { Red, orange } \\
\text { yellow, } \\
\text { orange red }\end{array}$ \\
\hline Guihu Ginkgo & ginkgo & $\begin{array}{l}\text { Ginkgo } \\
\text { bilobac } \\
\text { eae }\end{array}$ & golden \\
\hline Metasequoia lanceolata & $\begin{array}{l}\text { metasequo } \\
\text { ia }\end{array}$ & $\begin{array}{l}\text { Taxodia } \\
\text { ceae }\end{array}$ & Crimson \\
\hline $\begin{array}{l}\text { Maple forest in ancient } \\
\text { Dongchun }\end{array}$ & maple & $\begin{array}{l}\text { Acerace } \\
\text { ae }\end{array}$ & $\begin{array}{l}\text { Red, orange } \\
\text { yellow, } \\
\text { orange red }\end{array}$ \\
\hline $\begin{array}{l}\text { The international } \\
\text { Camellia valley of } \\
\text { Quanzhou }\end{array}$ & Camellia & $\begin{array}{l}\text { Theacea } \\
\mathrm{e}\end{array}$ & $\begin{array}{l}\text { Red, pink, } \\
\text { yellow }\end{array}$ \\
\hline $\begin{array}{l}\text { Datura manor in } \\
\text { Xing'an }\end{array}$ & Camellia & $\begin{array}{l}\text { Theacea } \\
\mathrm{e}\end{array}$ & $\begin{array}{l}\text { Red, pink, } \\
\text { white }\end{array}$ \\
\hline Xishan Park & $\begin{array}{l}\text { Plum } \\
\text { blossom }\end{array}$ & $\begin{array}{l}\text { Rosacea } \\
\mathrm{e}\end{array}$ & $\begin{array}{l}\text { Yellow, pink } \\
\text { and white }\end{array}$ \\
\hline Chuanshan Park & $\begin{array}{l}\text { Plum } \\
\text { blossom }\end{array}$ & $\begin{array}{l}\text { Rosacea } \\
\mathrm{e}\end{array}$ & Pink, pink \\
\hline Zizhou Park & tulips & $\begin{array}{l}\text { Liliacea } \\
\mathrm{e}\end{array}$ & $\begin{array}{l}\text { Pink, red, } \\
\text { purple, } \\
\text { orange red, } \\
\text { white }\end{array}$ \\
\hline
\end{tabular}

\section{Tourist preference analysis}

In this paper, Baidu Index search platform is used to calculate the network search volume of all plant landscapes in Guilin from January 2019 to January 2020, and input it as a field into ArcGIS. The spatial and temporal differences of tourists' preferences in different landscapes are analyzed by using the visualization function of ArcGIS. 


\subsection{Analysis of attention degree of scenic spots}

(1) According to the overall preference analysis

It can be seen that the plant landscapes with higher tourist preference in Guilin are mainly distributed in Qixing District, Xiufeng District and Xiangshan District, and five counties including Xing'an County, Yangshuo County, Gongcheng Yao Autonomous County, Longsheng Autonomous County and Pingle county. Among them, Gongcheng Yao Autonomous County has two plant landscapes with more than 10000 heat, which are Gongcheng Peach Blossom Festival and Gongcheng Yueshi. Among all the plant landscapes, the highest temperature of banyan in Yangshuo is 576000, followed by Longji terrace (297000) and Ginkgo biloba (199000) in Yangshuo County, Longsheng Autonomous County and Linchuan County, respectively. On the whole, the plant landscape with more than 10000 heat is mainly concentrated in the municipal area, and the distribution is more concentrated and the number is more. The plant landscape with a heat of more than 100000 and a plant landscape below 10000 are scattered in each county.

(2) Seasonal preference analysis

On the whole, spring plant landscape has more than 10000 hot spots, the most widely distributed, but the lack of more than 100000 high visibility landscape, such as Yangshuo banyan. In summer, there are more than 8.2 million wellknown plants in the West Flower Park, which are lower than 1 million in summer. The preference of autumn plant landscape is the highest in the four seasons, which shows that there are two plant landscapes with heat above 100000, which are Longji terrace (297000) and Haiyang town Ginkgo (199000), respectively, and the tourism popularity ranks first in Guilin.

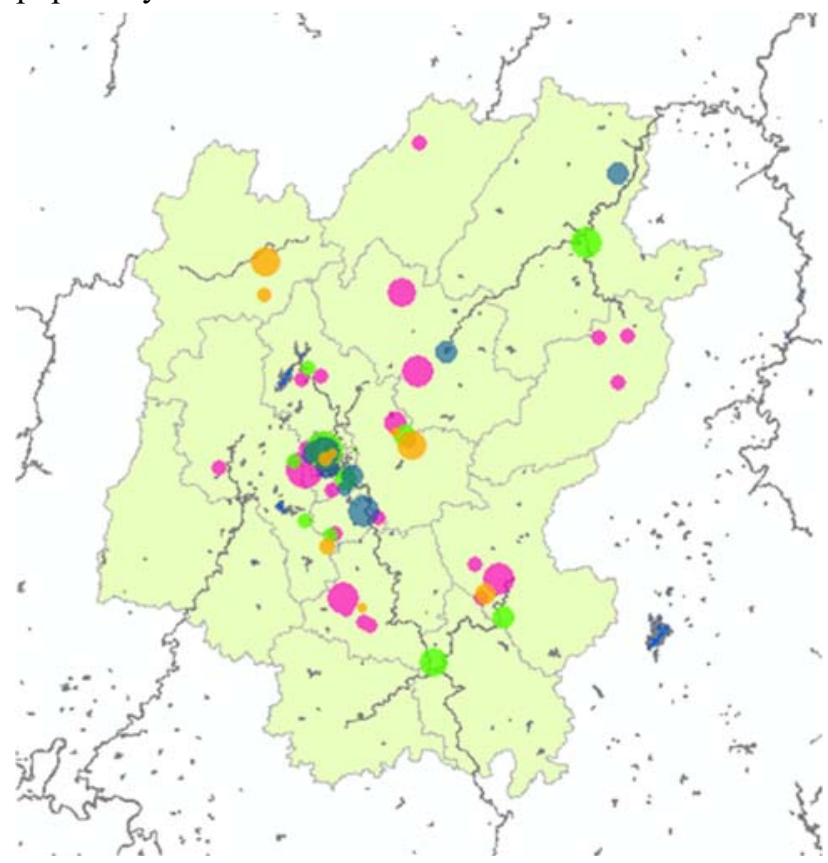

Fig. 5. Preference distribution of plant landscape in Guilin

\subsection{Analysis of tourism experience}

The author uses ROST CM6 software to make statistics on the tourist reviews of the top ten plant scenic spots in Guilin, and divides them into three categories according to the total word frequency

(1) Plant landscape with high tourist image perception Yangshuo banyan tree scenic area and Longji terrace scenic area are the two most famous scenic spots with plant landscape. (1) From the part of speech analysis: more nouns, higher frequency of words in addition to the description of plant landscape, such as banyan (133), terrace (303), ancient trees (10) and other words frequency is also higher. Words related to place names include: Shili Gallery (16), Yangshuo (21), Jinkeng (47), Ping'an (43). (2) From the perspective of attention, banyan tree and terrace are the core elements to attract tourists, ranking first in high frequency words. Some cultural factors have also become an important factor affecting the attractiveness of plant landscape. For example, banyan is the location of the film "Sanjie Liu" and it is also driven by Guilin's famous Yulong River scenic spot.

(2) Plant landscape with moderate tourist image perception

It can be seen from the word frequency analysis Table, Ginkgo biloba, Sapium sebiferum, cherry blossom and other representative landscapes are the core elements to attract tourists. The publicity of these scenic spots is often better, and some activities have also expanded its popularity, such as the Cherry Blossom Festival in nanxishan park. However, the word frequency of lotus in Xishan Park is relatively lower, which shows that the attraction of lotus as a characteristic landscape of the park needs to be improved.

(3) Plant landscape with low tourist image perception

Gongcheng Yueshi, Zizhou park red leaf, tulip, Dalingshan peach blossom, Liangjiang and four lakes scenic spots have low visibility. There are few related network texts and comments. The most frequent words were persimmon (49), red leaf (93), tulip (17), peach blossom (24), etc.

\section{Conclusion}

There are great differences in the spatial distribution of seasonal landscape preference in Guilin, which is mainly manifested in the overall high tourist preference, large number and wide distribution in spring. In summer, the plant landscape preference is generally low, the number is small and the distribution range is small. The plant landscape preference in winter is generally between spring and summer, and the distribution is relatively concentrated, and more than $2 / 3$ of them are distributed in the municipal area. The preference of autumn plant landscape is significantly higher than that of the other three seasons, showing the characteristics of low aggregation and concentrated heat. Compared with other plant landscapes, the number of UGC in Longji terrace and marine Ginkgo biloba was more than 100000.Through the analysis of tourists' online reviews, it is 
found that banyan, rice, cherry blossom, gingko and lotus get higher tourist preference, while the preference of grass, pear flower and tulip is lower. In addition, Liu Sanjie, Cherry Blossom Festival, persimmon Festival, history, stone carvings, Shili gallery and other words have a high frequency, which indicates that the promotion of A-level scenic spots and the development of related activities also increase the tourist preference of Guilin plant landscape.

Through the analysis of the differences in time and space of Guilin plant landscape tourists' preferences, this paper provides good reference and suggestions for tourists' travel. At the same time, the development and scientific management of plant landscape in Guilin has a constructive role. However, this paper only takes Baidu Index and online reviews as examples, which can't fully reflect the tourists' preference and attention of plant landscape in Guilin, so the conclusion of the analysis may not be comprehensive. In order to make the research of UGC better serve the scenic spots and tourists, the coupling analysis and prediction of UGC and real passenger flow, the relationship between network text and tourism economy, and the related factors influencing network attention should be carried out in the future.

\section{Acknowledgements:}

This work was supported by The National Key Research and Development Project of China (2019YFC05075033 ) ; Guangxi Natural Science Foundation Program (2018GXNSFAA050068)

\section{References}

1. Chunjiao Li, Jia Peiyi, Dong Li. Procedures and methods of plant landscape planning and design in Landscape Architecture [J]. Chinese garden, 2014,30 (01): 93-99 Enlai L, Qianqian L. The role of antipollution plants in environmental protection $\mathrm{J}$. Modern rural science and technology, 4 (2016): 50

2. Wenyou. Research on plant landscape space construction in Guilin City [J]. Agriculture and technology, 2015,35 (04): 145 research on tourism landscape attention based on spontaneous geographic information: a case study of Jiuzhaigou [J]. Wang Shoucheng, Guo Fenghua, Fu Xueqing, Li Renjie. Tourism journal. 2014 (02) Danjing Y. Effects of soil organisms on Phytoremediation of heavy metal contaminated soil J. Beijing agriculture, (2014): 275276

3. Xu Fan, you Wei, anniversing, Hu Meijuan. Research on spatial and temporal distribution of cyberspace attention based on Baidu Index: a case study of 5A scenic spots in Yangtze River Delta [J]. Resource development and market, 2016,32 (04): 489-493 4.

4. Xiaoqian $\mathrm{He}, \mathrm{Liu} \mathrm{Yu}, \mathrm{Wu}$ invent. Research on spatial and temporal characteristics of hot spring tourism network attention based on Baidu Index. Regional research and development, 2017, 36 (1): 103-108124 Wenbin H. Coal mine air pollution and control countermeasures J. Environment and development, (2017): 64,66

5. Liwei Zhang. The impact of network attention on the trading volume of P2P platform: An Empirical Study Based on Baidu Index. Investment research, 2016, 35 (6): 130-148

6. Xiaoying Xiao. An Empirical Study on rural leisure tourism based on tourists' perception: a case study of Yanling. China Agricultural Resources and regionalization, 2015, 36 (5): 78-81

7. Gaojun Zhang, Junyi Li, Zhang Liu. Research on tourism image perception of Huashan Scenic Spot Based on text analysis of tourists' weblog. Tourism science, 2011, 25 (4): 87-94 